\title{
Making sense of Australian sport history
}

Daryl Adair

Despite the high profile of sport in Australian culture, the historical analysis of sport in this country has not attracted much coverage, whether in terms of academic research, media interest, or the reading public. Australian sport fans are eager to recount glorious performances by the nation's teams and athletes, and they certainly indulge in eulogistic books and magazines about sport. But these enthusiasts have comparatively little knowledge about, or interest in, Australian history and the role of sport in shaping its evolution. This is, in large part, a reflection of inadequate education: in many schools history has been supplanted as a key area of study, with the Australian story conveyed as part of broad brush subjects like 'social studies' or 'civics and citizenship'. Moreover, at university level Australian history is typically taught with scant regard for the explanatory potential of sport and physical culture. Too often, sport has been relegated by Australian academics to the 'toy department' rather than the history department where, incidentally, there are few scholars for whom sport is a serious focus of research (Booth 1997; Adair 2002). This is illogical, because sport can provide important insights into themes and issues that have been pivotal to the evolution of Australian culture. Indeed, as this chapter indicates, sport historians have carved out areas of research that contribute ably to the study of Australia's past. The following discussion is a thematic overview of Australian sport history with a focus on three pivotal areas: national self-image through sport, norms of sport participation, and the involvement (or otherwise) in sport of so-called minority groups. Together they provide metaphorical windows through which to try to make sense of Australian society and culture, and the role of sport in their historical evolution.

\section{Australian self-image through sport}

According to historian Geoffrey Blainey (1966), Australia has been cursed by the "tyranny of distance'. As a British colonial outpost it was literally on the other side of the world, and, particularly before air travel and electronic communication, this meant separation from the so-called motherland. Sport was one way in which Britain and its colonies, whether in Australia or elsewhere, could be connected. It was, as both Daly (1982) and Cashman (1995) have averred, part of the cultural baggage of migrants - particularly those who arrived as free settlers in the second half of the 19 th century. Efforts to establish race tracks, cricket fields and rugby pitches were part of the colonial drive to recreate - even if in the 
imagination - some of the cultural trappings of a distant 'homeland'. There was fanfare and excitement when sports teams and competitors from Britain toured the colonies. The locals were initially in awe of visiting athletes, such as in cricket, where English sides toyed with their colonial counterparts. But, as historians have shown, from the 1860 s onwards the tide slowly turned - most notably in cricket, rowing, and Rugby Union - with Antipodean teams and crews performing creditably in Anglo-Australian contests (Adair 1994; Adair et al. 1997). The importance of this sporting relationship was firmly established in 1882, when the legend of the 'Ashes' was born in the wake of a surprise Australian win over England at The Oval in London. That victory, together with other triumphs in sport, impacted positively on colonial self-confidence; athletes and teams were eagerly representing 'Australia' abroad before the nation existed (Cashman 1992). They were still fiercely pro-Empire, but anxious to overcome negative attitudes about a convict past and rumblings about Antipodean inferiority (Hirst 1983; Hughes 1987). Sport, with its immutable scoreboard, was thus an important way of establishing a sense of Anglo-Australian parity - and ultimately rivalry.

Mandle (1973) sees in sport, though most notably in cricket, seeds of colonial nationalism that went beyond culture into politics. Australians were for many years lukewarm about the idea of Federation, and it took two referenda for that proposal to be passed - and eventually by only a small majority (Norris 1975). Mandle (1973) contends that intercolonial and AngloAustralian sport provided examples of effective administrative cooperation at the national level, which many had thought unlikely in an era when parochial colonies protected their local economies with tariffs and, by producing differently sized railway gauges, effectively stymied regional trade and travel. This rather 'reluctant' Commonwealth of 1901 provided a very hybrid sense of nationhood (Meaney 2001; McGregor 2006). Australia remained a dominion of the British Empire and would continue to prove its loyalty to Britain by military service in the Boer War and two world wars. Through 'Empire' sports like cricket, Rugby Union and Rugby League, together with active support for British troops in Europe, Australians developed a formidable reputation on both playing fields and battlefields. This combination of sport and wartime service has received attention by scholars interested in questions of identity, loyalty and gender norms (McKernan 1979; Blair 1995; Phillips 1996, 1997; Jaggard 1996; Rodwell \& Ramsland 2000; Crotty 2001; Ramsland 2004; Cohen 2006). But the subject has not been treated exhaustively - surprisingly so given the depth of interest in military history in Australia and the elevation of the ANZACs to the status of a legend (Seal 2004).

The use of space and response to climate are lynchpins of Australian history. With European annexation of land, many colonists looked to establish agricultural properties and mining operations in rural or remote areas. They were the exceptions. Most whites resided in urban centres along the outer rim of a vast, largely dry, island continent. There they had ready access to the ocean and regular supplies of water from coastal river systems - both of which also provided opportunities for aquatic sports (Drew 1994). The city of Sydney with its sunny weather, panoramic harbour and lengthy Parramatta River, provided regular opportunities for sailing and rowing regattas, which proved to be some of the most popular sporting spectacles of the 19th century (Cashman \& Hickie 1987; Adair 1992). Today, of course, some of the most iconic recreational spaces in Australia are beaches, with both surfers 
and surf lifesavers quintessential symbols of local aquatic culture (Saunders 1998). Yet, as historians have shown, during the colonial era there was conflict between picnickers and surf bathers, and efforts to proscribe swimming in public. For many moral conservatives, bathing at the beach in daylight hours was frowned upon as improper, exposing too much flesh at a time when modesty was acute (Brawley 1995; Booth 2001 b; White 2004; Jaggard 2006). Indeed, when public bathing eventually became more widely accepted, whether at the beach or in swimming pools, men and women were initially segregated (Phillips 1998; McDermott 2005). Surf lifesaving - an Australian invention - dates from 1907, but until recent decades this was a male-dominated institution. The timing and extent of gender reform is, however, still hotly debated by sport historians (Booth 2000, 2002; Jaggard 2001, 2002; Phillips 2002).

As a public space, the beach provides historians with a fascinating resource for tracking changing perceptions about the human body and norms of public behaviour. Surfing, for example, became part of a 1960s beachside 'counterculture' in which self-expression and aesthetic movement in the surf were highly prized. New swimwear was intended to accentuate body display, and was soon commercialised as a fashion item (Booth 2001b Daley 2005). Booth's research has revealed structural tensions at the modern beach. 'Surfies' preferred to stay aloof from formality and civic engagement, while surf lifesavers volunteered their time to clubs and the wider beach-going community. To the lifesavers the surfies appeared self-indulgently radical; to surfies the lifeguards seemed subservient and conformist to authority. These were convenient stereotypes; both of these male-dominated groups could, in their own way, be a law unto themselves. Lifesaving clubs were ideal places to drink heavily, and many were sponsored by alcohol companies or pubs. Surfers, meanwhile, were more likely to experiment with illicit drugs. None of these substances was conducive to optimum motor skills or water safety (Booth 1991, 1994a, 1994b, 2001a, 2001c). Today many of the best Australian surfers are part of a global professional circuit, with performance and style being rewarded in cash (Booth 1995). Concurrently, surf lifesaving clubs have sought to curb excess drinking, make membership more gender inclusive, and actively recruit volunteers from culturally and linguistically diverse backgrounds. Indeed, a positive response to the infamous Cronulla Beach riots of 2005 , which involved conflict between ultranationalist 'whites' and beachgoers of Middle Eastern background, has been Surf Lifesaving's 'On the Same Wave' program, which has actively recruited volunteers from diverse ethnic and cultural backgrounds.

While space, place and geography are pivotal to our understanding of Australian history, these subjects have yet to be developed extensively by sport historians. Indeed, although regional differences have been noted about sport around Australia (Cashman \& Hickie 1982; Forster 1986; Bennet 1988; O'Hara 1991, 2002; Magdalinski 2002; Topp \& Nauright 2004; Atherley 2006; Horton 2006), there is no systematic geographically informed or comparative research - certainly nothing to rival the comprehensive work of John Bale in Britain (Bale 1994, 2003). Our notions about athleticism, identity and self-image are therefore lacking a demonstrated awareness of similarities and differences about sport and history across what is, after all, a vast continent with varying terrains, climates, populations 
and cultures. And, as is now discussed, there were key norms and power relationships in society that established boundaries of inclusion and exclusion within sport.

Norms of participation in Australian sport

The Australian colonies did not reproduce a class system based on nobility. There were selfstyled migrant aristocrats from Britain, but in the Antipodes elevated status was shaped overwhelmingly by holding public office or 'making good' economically. Australians were not equal in wealth or power, though there was a commitment to opportunity; an achievement culture. Those who 'made it' were, however, frowned upon if they adopted 'airs' and 'graces.' Hirst (2006) has described this as 'a democracy of manners' and contends that 'it is the feel of Australian society that is markedly egalitarian, not its social structure' (p. 301). This hypothesis can also be usefully applied to Australian sport. Sociologists have done much to dispel widespread assumptions that sport is structurally egalitarian in contemporary society. Yet they also note the persistence of discourses that present sport as inherently 'open to all' (Lawrence \& Rowe 1986; Stoddart 1986; Rowe \& Lawrence 1990; McKay 1991). Historians, meanwhile, have tried to put inequalities in context: class and status divisions in sport were typically more pronounced in the 19th and 20th centuries than today, and some sports were more elitist than others.

In late Victorian England there was a serious divide between professional and amateur versions of sport. This schism soon impacted on Australia, particularly as rules for the amateur code tended to be drawn up in Britain (Holt 1989; Cashman 1995). In the colonies there evolved amateur and professional versions of sports like rugby football (Cunneen 1979; Horton 1994; Collins 2000, 2005; Little 2007), athletics (Ross 1984; Mason 1985; Daly 1994); cycling (Hess 1998; Weaver \& Weaver 1999; Simpson 2006) and rowing (Adair 1992, 1994). A further sporting innovation from abroad was the Olympic Games, where amateur status was needed for eligibility to take part. Hence there was considerable surveillance of sports to which prize money and wagering were attached (Jobling 1988). By and large, though, the amateur code was read and applied more stringently in Britain than in Australia. With rowing, for example, English clubs not only banned participants who had competed for a wager or prize money, they eventually imposed a test of status and privilege - anyone deemed working class was proscribed from membership of an amateur club (Halladay 1990). In Australia, however, non-pecuniary amateur status was more important than class background; hence the introduction of a manual labour amateur classification at many rowing clubs (Adair 1992, 1994; Crotty 1998; Ripley 2005). In Australian sport the amateur code was open to very different interpretations, and the penalties associated with transgressions varied; officials could be very harsh while some conveniently turned a blind eye. This was very much sport and politics (Moore \& Phillips 1990; Cashman 1995, pp. 54-71; Adair \& Vamplew 1997, pp. 37-40; Phillips 2001a; Senyard 2002). It used to be thought that amateur and professional sport in Australia were entirely separate domains. Recent research, however, has thrown that easy assumption into disarray. In mid-19thcentury rowing, for example, it was quite common to offer prizes to amateur victors and this did not compromise their amateur status. What was more, they often competed on the same program (though generally in different events) as professional competitors (Adair 
1992, 1994; Senyard 2002). Most startling of all, though, Stuart Ripley (2003) revealed that some of Australia's leading sport officials presided over both amateur and professional competitions during the late 19 th and early 20 th centuries.

In terms of the evolution of amateur and professional modes of elite sport in Australia, much has changed since the advent of live television broadcasts in the 1970s. Significantly, neither tennis nor cricket offered long-term professional careers within Australia until players sought, in effect, a slice of the TV revenue being earned by not-for-profit sporting bodies. However, while there has been much debate about the World Series Cricket 'revolution' that spawned the rise of full-time professional cricketers in Australia (Harriss 1990; Stewart 1995; Haig \& Dundas 2001), remarkably little has been written about the schism in Australian tennis, wherein some of the great players of the 1950s and 1960s turned professional at a time when the Majors were for amateurs only (Fewster 1985; KinrossSmith 1994). Golf provides another complex scenario: professionals in private clubs of the early 20th century were modestly paid coaches or lowly paid caddies appointed to serve the interests of members, with many of the latter coming from wealthy backgrounds. This 'master and servant' relationship has now evolved to the point where a club professional holds a position of considerable status, and the burgeoning prize money offered on Australian and overseas circuits has raised the income of the elite golfer and caddy into the upper echelons of athlete income (Stoddart 1994).

Tennis and golf are also interesting historically because they have long been sites of public access or private privilege. The fees associated with membership of a private club have always acted as an economic filter, but so too has social vetting of members by club boards. Curiously, though, too little is presently known about questions of inclusion and exclusion in two of Australia's best-known participant sports (Phillips 1988, 1990; Tatz \& Stoddart 1993; Kinross-Smith 1994, 1997; Blashak 2004). Indeed, there is a general lack of systematic historical analysis into questions of class, status and privilege in a range of emergent elite sports like sailing, motor racing and horse racing, where wealth and social position impact on membership of private clubs and the capacity to own yachts, grand prix cars, and thoroughbred horses (O'Hara 1994, 2007; Griffen-Foley 2000; Thompson 2004). The eminently popular Melbourne Cup is perhaps the quintessential example of Hirst's dictum about structural inequality and a 'democracy of manners' in Australia. This horse race literally stops much of the nation for two minutes on the first Tuesday in November; to that extent it is a shared celebration. However, Flemington racecourse separates spectators according to their status as club members, horse owners and 'ordinary' punters. They might be at the same event, but the idea that all classes 'rub shoulders together' on Melbourne Cup Day - whether at the race course or over a champagne lunch - is one of the nation's most alluring myths (Beresford 1982; Ahearne 1987; White 2003).

Australian schools have long been nurseries for major sports like Rugby Union, Rugby League, Australian Rules football, cricket and netball. Back in the 19th century there was a particular effort by denominational schools to instil in pupils the British-inspired athletic ideal of 'muscular Christianity', within which amateurism was a core value. This not only applied to Anglican and Protestant schools; amateurism was a hallmark of Irish sport too, 
hence its significance within Catholic education (Cronin 1996; McDevitt 1997; Brice 2001; Watson 2005). A major examination of sport, religion and ideology in Australian history nonetheless awaits (key publications include Crawford 1986; Brown 1987; Connellan 1988; Stewart 1992; Crotty 2000). Perhaps the biggest gap, though, is in our historical understanding of varying physical education and sport opportunities for children across the two educational systems: state-funded, secular schools and state-subsidised, private schools (Collins et al. 1990; Kirk \& Twigg 1993, 1995; Kirk 1996; Wilkinson 1998). For example, in Sydney, a small elite clique known from 1892 as the Amateur Athletic Association of the Great Public Schools (AAAGPS) of New South Wales (or Great Public Schools) has provided sport facilities and resources, such as rowing sheds, swimming pools and tennis courts, that are typically absent from the grounds of non-selective state schools and second-tier independent schools. One of the major events on the GPS sporting calendar is the exclusive 'Head of the River' rowing regatta, which dates back to 1893 and is modelled on boat races among the elite public schools of England (Sherington 1983). Sydney's GPS schools have been a traditional nursery for recruitment into New South Wales Rugby Union clubs; and, since the majority of these schools catered for boys rather than girls, the social construction of masculinity through body contact sport (Light \& Kirk 2000, 2001). This is not to suggest that girls have had no place in school sport, either in the state or private systems. But it has been very much a secondary place. For example, not until 1996 did female students in New South Wales have their own Head of the River regatta (Crawford 1984; Stewart 1992; Kirk 2000).

Gender identities and associated norms of physicality are indeed keys with which to investigate sport in Australian history. It has been largely a male domain, as elsewhere. Scholars have shown that for many young boys sport has been a significant rite of passage into manhood. This reflects longstanding cultural assumptions that boys are 'inherently' combative and aggressive, and that sport provides a focus for such overtly 'masculine' behaviours (Nauright \& Chandler 1996; Light \& Kirk 2000; Hickey 2008). For young females the reverse has been true; until the late 20th century girls had fewer opportunities to participate in sport, and they were often encouraged to undertake 'female appropriate' activities, such as netball, that did not compromise traditional notions of femininity (Treagus 2005; Taylor 2005). Even today, with important efforts to improve female access to a range of sports, the institution of sport itself remains a key to the gendering process. Not only are men and women typically separated in competitive physical activity, but at the elite level, females are celebrated as athletes of calibre on too few occasions - such as Olympic and Commonwealth Games, where they receive equal media coverage alongside men (Phillips 1997; Adair \& Vamplew 1997, pp. 48-62; Payne 2004).

The history of women in Australian sport has been characterised, on the one hand, through radical feminist criticism of marginalisation and oppression by males (Randall 1988); and on the other hand, through liberal feminist arguments that women have indeed been more active in sport than many (male) historians have bothered to notice (Stell 1991). There is, however, little debate about one point: as the work of Dennis Phillips has shown, Australian women have repeatedly outperformed their male counterparts in terms of procuring medals at the Olympic Games. His research offers an alternative way of recognising and 
valuing female sport achievement (Phillips 1990, 1996). Similarly, Rob Hess has examined the historical importance of women as sports fans; their contribution as supporters of Australian Rules football, in particular, is unsurpassed by any other code (Hess 1996, 2000, 2005). Today, though, the analysis of women in Australian sport history seems to have reached a hiatus; the 21 st century has yet to produce a wave of new research despite the welcome efforts of a small number of enthusiasts (Burroughs \& Nauright 2000; Haig-Muir 2000, 2004; Brabazon 2000; Burroughs 2001; Little 2001; Hess 2000, 2005; Taylor 2005).

The historical analysis of group identity, inclusion and exclusion in Australian sport must also engage with societal issues for Indigenous peoples, other non-whites and ethnic minorities generally. As the following discussion indicates, this means taking seriously endemic problems of racism and the stereotyping of 'others' on the basis of their skin colour or ancestry.

Aborigines, non-whites and ethnic minorities in Australian sport

Well before the arrival of Europeans and the subsequent British annexation of Terra Australis, a vast array of Aboriginal peoples were custodians of the land and sea. They were regionally disparate and spoke different languages, but had much in common. This included an ingenious capacity to observe, understand and respect the natural environment, a constructive mutualism that enabled co-existence for at least 40,000 years. Aborigines were spatially aware and physically dexterous; they needed these attributes when fishing and hunting for food. It was here that play, games and sports provided input. Within Aboriginal communities there were games of strategy and play activities requiring athleticism and dexterity. Footraces promoted speed, ball games fostered agility, while spear and boomerang throwing contests demanded eye-to-hand coordination important for hunting (Howell \& Howell 1992; Edwards 1999, 2009). However, Aboriginal societies were fragmented by European annexation of land, with many Aborigines confined subsequently to colonial reserves and missions. This dislocation meant that traditional Aboriginal sports and games began to lose their functional relevance, with the meaning and significance of such activities not passed onto later generations. A decline in these customs was part of a wider diminution of Aboriginal culture and identity under European colonisation (Smith 2008).

Recently, there have been efforts to trace, record and revive traditional Indigenous games. Using the medium of oral history, Queensland academic Ken Edwards has spent many years talking with Aboriginal and Torres Strait Islander elders. Through this dialogue, as well as by reading early anthropological accounts, he has established a formidable record of customary Aboriginal recreation (Edwards 1999). That knowledge now has applied significance because Edwards, with the assistance of the Australian Sports Commission, has produced a user-friendly booklet for schools and community groups which explains the traditional purpose of particular Indigenous games and how they may be played today (Australian Sports Commission 2009, Edwards 2009). This is a significant development: through sport and recreation non-Aboriginal Australians can be introduced to aspects of a living culture. Too often Indigenous history and customs are neglected as 'irrelevant' in discourses of modernity in Australia. 
Histories of Aboriginal responses to colonialism, and the regime of controls exerted on Indigenous peoples by representatives of the British Crown, have developed significantly over the past 20 years (c.g. Reynolds 1996, 2006). So too, stories of the various missions that institutionalised Aborigines and separated them from European settlers (Stevens 1994; Mitchell 2005). This confinement introduced Indigenous people to the language, religion and customs from Britain. That process of colonial acculturation included sport - most notably the game of cricket - as a means of instilling in Aboriginal boys and men agreement on rules, respect for the decisions of those in authority, and a common goal of teamwork in a competitive setting. It seems remarkable, at first glance, that in 1868 the first 'Australian' cricket team to tour England consisted almost entirely of Aborigines. However, as historians have shown, this was an entrepreneurial initiative on the part of non-Indigenous sponsors and management, who saw an opportunity to draw big crowds and significant revenue for themselves from a series of exhibitions abroad - involving both cricket and displays of Aboriginal physical culture (Mulvaney \& Harcourt 1988; Sampson 2000 , 2009). The Aboriginal cricketers performed ably, winning as many games as they lost. But this did not establish Indigenous players in Australian cricket back home. Indeed, although there were some fine young Aboriginal cricketers in the late 19th and early 20th centuries, they faced significant obstacles to play at the elite level (Whimpress 1992, 1999). There were logistical problems owing to laws that constrained the movement to cities of Aborigines impounded on rural missions and reserves. What was more, as sport historians have shown, the few Indigenous players who did make it to first-class cricket had chequered experiences, such as outstanding bowlers Jack Marsh and Eddie Gilbert, both of whom had problems with cricket officials that negated their opportunity to play for Australia (Whimpress 1994; Colman \& Edwards 2002; Bonnell 2003).

Despite negative Aboriginal experiences in cricket, Newlin and Moran make the salient point that 'there have always been Aboriginal achievers in sport, but few people know this' (Newlin \& Moran 1999, p. 35). Sport historians, led by Colin Tatz, have tried to rectify this lack of awareness, while also detailing ways in which Aborigines have been discriminated against in sport and society (Tatz 1987, 1995). Indigenous athletes were most likely to appear in activities that offered the prospect of financial reward; amateurism was a white, middle-class philosophy of privilege that was not relevant to their circumstances. No surprise then that Aborigines featured in prize-money events, particularly pedestrianism (sprinting), boxing, and as jockeys in horse racing (Broome 1980, 1996; Blades 1985; Mooney \& Ramsland 2008). But they were generally not to be seen in sports that required expensive equipment, such as sailing and rowing. For the most part, they were also absent from the membership of private clubs like golf and tennis.

When Australia was proclaimed a Commonwealth in 1901, the restrictive White Australia Policy (WAP) was enshrined in law. The focus of this federal legislation was non-English speaking immigrants and (de facto) people of 'colour' seeking to be residents of Australia. However, short-term visitors could, with the support of a local sponsor and the consent of immigration authorities, be provided with an 'exemption certificate' that temporarily overlooked their 'alien' or 'coloured' status (Honey 2001). Intriguingly, this loophole allowed occasional visits by non-white, 'foreign' athletes who performed publicly at 
Australian sport venues. Notwithstanding the racial separation implicit in the WAP, local sport fans typically appreciated the athletic skills and 'exotic' appearance of these 'coloured' competitors. However, there were also differences of opinion and reaction. AfricanAmerican boxer Jack Johnson was admired for his boxing prowess, but hated by many for defeating a white title holder in Sydney in 1908 (Broome 1979; Wells 1998; Headon 2009). Yet only two years earlier African-American cyclist Marshall 'Major' Taylor had beaten all comers in Sydney and was widely coveted by local sport fans (Ritchie 1996, 2010). In 1915, the man widely accredited with giving surfing a high profile, Hawaiian Duke Paoa Kahanamoku, was revered when he took to the waves in Australia (Osmond et al. 2006). Similarly, Alick Wickham, a Solomon Islander in Australia, became the most famous exponent of the 'crawl' stroke (Osmond \& Phillips 2004; Phillips 2006). Visiting athletes of Asian origin were less renowned in Australia but do not seem to have been excluded from local sporting culture (Osmond \& McDermott 2008). Indeed, despite local fears of eventual invasion by the so-called yellow peril from East Asia, swimmers from Japan and footballers from China were received very hospitably during the 1920s (Guoth 2007; Brawley 2009). There is plenty of irony about athletes of non-white appearance being accorded such status; not only because of the WAP, but because in the first half of the 20th century Indigenous Australians had such a low profile in the nation's sporting culture (Whimpress 2001).

There were signs of change in the 1960s and 1970s. When Aboriginal boxer Lionel Rose claimed the world bantamweight title in Japan in 1968, he was mobbed by well-wishers upon return to Australia. Not only was Rose the first Aborigine to win a world boxing title, he also became the first Indigenous person to be awarded the prestigious title of 'Australian of the Year'. A year later he reached the top of the music charts with a country and western song 'I Thank You' (Rose \& Humphries 1969). Along with tennis player Evonne Goolagong, who twice won the Wimbledon singles crown, Rose presented the image of an Aborigine who had 'made it' in white society. Like Cathy Freeman, who lit the cauldron at the opening of the 2000 Olympic Games, both Rose and Goolagong appealed to many white observers who, ordinarily, had little contact with or sympathy for Aboriginal dissidents, such as those who fashioned the Aboriginal Tent Embassy in Canberra in 1972 (Goolagong-Cawley 1993; Bruce \& Hallinan 2001; Lothian 2007); or, for that matter, Aborigines who took their protests about land rights to the streets during the Commonwealth Games of 1982. In the latter case the Queensland government was so 'spooked' by this Aboriginal assertiveness that it declared a state of emergency in order to constrain such public demonstrations (Tatz 1981, 1984; Shannon 2004). Rose and Goolagong presented to white Australians 'nonthreatening' examples of Aboriginal advancement.

During the 1980s and 1990s increased numbers of Indigenous males participated at the elite level in the country's two largest football codes - Australian Rules and Rugby League. By the early 21 st century players from Aboriginal or Torres Strait Islander heritage constituted around $10 \%$ of all professional players in both the AFL and the NRL - a staggering proportion, given that the Indigenous population of Australia is about $2 \%$ of the national total (Korf 2009). As scholars have shown, however, these footballers battled long and hard against racism on and off the field. Not until the late 1990s did football administrators have anti-vilification policies fully in place, and they were in effect pushed 
into doing so by outspoken and articulate players like Essendon's Michael Long (Gardiner 1997; Warren 1997, 2000; McNamara 2000). The profile, status and remuneration of professional Indigenous athletes has never been better (Tatz \& Tatz 1996, 2000), but there remains more to be achieved - particularly in terms of career transition planning and retirement experiences of Aboriginal sportspeople (Stocks \& East 2000; Gorman 2005; Stronach \& Adair 2010).

Issues of discrimination and stereotyping in sport have also been apparent among ethnic minority groups in Australia. While soccer, for example, was an important sport for the great flood of European migrants after World War II, the game was typecast as 'foreign' by comparison to the existing staples of the rugby codes and Australian Rules (Hay 2006). Soccer was commonly ridiculed as 'wogball' and a game for 'poofters'; this derision not only impacted upon so-called New Australians playing soccer, but residents of AngloCeltic heritage with a passion for the sport (Warren et al. 2002). Ethnicity has, of course, been part of Australian sport since the 19th century. Scots were particularly noticeable in golf and lawn bowls, Irish Catholics were prominent as bookmakers in the racing industry, while the English were especially zealous about cricket and fox hunting. These practices were basically extensions of migrant cultural baggage in the Antipodes (Adair 1998). But it would be misleading to speak of ethnic enclaves among the Australian population or within the sporting culture of the late 19 th and early 20th centuries. Indeed, despite protracted Anglo-Irish tensions, most notably after the Easter Rising of 1916, which had local impacts upon Australian society, sport appears to have been less affected by sectarianism than education, party politics and the public service (Hogan 1987; Kildea 2002). There have been suggestions that Irish-Catholic Test cricketers suffered discrimination at the hands of team mates and selectors, though there is debate among historians as to whether this was systematic persecution or merely a series of personality conflicts (Bairner 2007).

In Australia, historical research into sport and ethnicity has focused principally on the second half of the 20th century (Mosely 1997). It was given impetus as a subject for inquiry by the emergence of a federal government policy of multiculturalism, first adopted by Labor in 1973. Previously, New Australians were expected to assimilate into a dominant English-speaking, Anglo-Celtic culture. Now there was an emphasis on respect for group differences within a society that, as a consequence of mass migration - not only from Europe but increasingly Asia - had become more culturally diverse and ethnically cosmopolitan (Jupp 1991). In terms of sport, however, little seemed to change. For example, although a promising 19-year-old fast bowler, Len Durtanovich, played junior representative cricket for New South Wales, it was the pragmatically renamed Len Pascoe who played for Australia between 1977 and 1982. His parents' Yugoslavian origins were, however, still a source of derision for some cricket opponents (Lawson 1993; Haig 2004). Soccer, meanwhile, was still subject to discourses propounding it as a game for ethnic 'others' (minorities) and thus not 'true-blue' Australian (Hughson 1992; Danforth 2001). Sport therefore remained a culturally conservative institution within which traditional forms and norms of physical activity dominated. 
In the past two decades, however, there has been a greater emphasis on social inclusion and the engagement of various communities into sport - with a particular focus on attracting people from culturally and linguistically diverse backgrounds (CALD) (Taylor \& Toohey 1998). Yet this has coincided, ironically, with a move away from sports clubs dedicated to particular ethnic groups and towards the 'cosmopolitanising' of Australian sport culture - within which people of all ancestries and skin colours are assumed to have a place. On the one hand this has opened new opportunities, on the other hand it has represented loss. For example, sports clubs organised by and for Jews have a long lineage in Australia (Hughes 1996, 1999). This includes the Monash Golf Club in Sydney, named after Australia's renowned Jewish military commander of World War I. However, demographic and socioeconomic changes have in effect transformed Monash into a 'cosmopolitan' golf club, albeit with a Jewish past (Tatz 2002).

This theme of loss has also been noticeable among soccer clubs that were originally formed to cater for the fraternal needs of ethnic groups from non-English speaking backgrounds - Italians, Greeks, Serbs, Croats, and so on (Mosely 1995; Hay 1998). The profile and status of such clubs has been denuded since the mid-1990s by a National Soccer League (NSL) decision to in effect 'de-ethnicise' elite-level club competition in Australia (Hughson 1997). A key expectation was that club names be revamped in an attempt to garner fan support from beyond an 'ethnic' base. Greek club West Adelaide Hellas, for example, changed its name to the West Adelaide Sharks. This was part of an explicit effort to reinvent soccer as a game intended to appeal to 'mainstream' Australia, not just particular ethnic communities that many of the clubs appeared to represent (Westerbeek 2005). At the elite level, club soccer faced protracted financial and administrative difficulties, as well as a perception (sometimes created by the media) that matches between Serbs and Croats, for example, were little more than occasions for historic, European-based inter-group hostilities to be played out in an Antipodean setting (Hughson 2000, 2001; Hay 2001). Intriguingly, NSL efforts to 'mainstream' soccer were a contrast to strategies by the AFL and the NRL, both of which actively courted players and supporters from CALD backgrounds and, though they did not put it this way, a more conspicuously 'cosmopolitan' following (Stewart 2007).

No Australian sport has gone through more reform than soccer in recent decades; while this has involved loss it has also presented opportunity. The NSL has been supplanted by the A-League, which involves team franchises and single clubs representing cities or regions. It has received financial backing from Jewish-Australian property magnate Frank Lowy, while the long overdue involvement of the Socceroos in the World Cup (2006) gave the sport - renamed football in Australia - unprecedented profile and public following. Although it is early days, the 'mainstreaming' of football via the A-League and the expectation of the Socceroos participating regularly in the World Cup, appears to have the potential to put the game in a more stable financial position (Dabscheck 2007; Skinner 2008). What is more, preliminary research indicates that CALD fans of the NSL have, for the most part, not been isolated by the A-League, and that a new generation of football fans - from all sorts of backgrounds - are attending matches (Lock et al. 2008; Lock 2009). As with the Monash Golf Club there is both loss and opportunity; erosion of ethnic traditions, but a commitment to engage with a wider range of followers. It is an example of the growing 
diversity of Australian sport cultures. Of course sport and Australian nationalism persists, but for many people it is a hybrid sense of fan allegiance - Australian and Vietnamese, Australian and Serbian, Australian and Greek, and so on. Rather than a site of monolithic parochialism and patriotism, Australian sport - both in local and global contexts - appears to be moving towards a postmodern, cosmopolitan phase (Georgakis 2000; Bowden 2003).

\section{'Re-visioning' and revisiting Australian sport history}

As explained at the outset, there are very few career opportunities in Australia for academics aspiring to work as sport historians, and the vast majority of current practitioners are located in Human Movement, Sports Studies or Business environments within which historical analysis tends to have a low priority. That said, there have been some important contributions by Australians to the practice of sport history. Murray Phillips and Douglas Booth have been at the forefront of global initiatives to make the subdiscipline more receptive to innovations within social and cultural history generally. They have encouraged researchers to explicitly situate themselves within a theoretical paradigm; they have urged scholars to be more conscious of archives as sources of power, not simply evidence; they have prompted writers to reflect upon their research methods and their positions, as investigators, within that process; and they have emphasised the constructed and contingent nature of 'findings' (Phillips 1998, 2001; Booth 2004, 2005a, 2005b, 2006; Phillips 2006). Their counsel has so far received mixed responses: sport historians familiar with the 'cultural' or 'linguistic' turn in the discipline of History are well placed to benefit from both the Phillips and Booth recommendations, but those limited to conventional social history face something of a challenge from deconstructionism and postmodernism (Hay 2006b; Stoddart 2006; Johnes 2007; Guttmann 2008). Concepts like reflexivity and tropes, as well as methods of discourse analysis or semiotics are not grasped easily, in part because many who deploy them insist on highly specialised, even obtuse language. Thus the challenge for Phillips and Booth, world leaders in their own right, is to convey their arguments in a way that inspires others to follow.

While there has recently been important debate about a 're-visioning' of the craft of sport history, there are further priorities that need revisiting. First, remarkably little systematic research has been conducted into the economic history of Australian sport (Stewart 1985, 2003, 2007; Dabscheck 1991, 1998; Booth 1997, 2004). In Britain, by contrast, there is a wealth of knowledge about club ownership, profit and utility maximising behaviours, player salaries and unions, and so on. Classic examples include Vamplew (1976), Vamplew (1988) and Tranter (1998). Second, while there has been sustained research into the impact of the media on Australian sport since the late 1970s - the era when television became crucial to professionalisation and commercialisation (Lawrence \& Rowe 1986; Hutchins \& Phillips 1997; Rowe 1999; Phillips \& Hutchines 2003) - too little is presently known about the role and significance of the print media and radio in the formative years of Australian sport (Cunneen 1981; Grow 1986; Wenn 1993; Brown 1995; Stewart 2002). Such conventional forms of mass mediated sport are less significant in the age of digital television and the internet, but they are surely of major historical import. Third, there are distinctive aspects of Australian sport history that are well known but poorly understood. 
Why is it that professional clubs in the football codes and cricket have typically been member based rather than, as with soccer and baseball in Britain and the US respectively, either owned by individuals or shareholders? (Nauright \& Phillips 1996, 1997; Phillips \& Nauright 1999). What values and aspirations have been associated with club membership in Australian sport history? (Stemski 1986; Moore 1996; Phillips 1996; Lock et al. 2008). Why, in addition, is there no tradition (other than in soccer) of Australian sport spectators being formally segregated in stadia on the basis of team allegiance? What is more, given the passion typically associated with 'barracking' at Australian sport, why has the hard core 'hooligan' phenomenon been largely absent from the football codes Down Under? (Warren 2003). In sum, a key problem with Australian sports history is not simply a lack of theoretical or methodological vision, but a need to systematically revisit historical archives - documentary, visual and oral. Revisionism can emerge from reforms to the academic craft of sport history; equally they can arise from painstaking reading and interpretation of primary sources - many of which are as yet untouched by scholars of sport. May a new generation of scholars lead the way.

\section{References}

Adair, D. (2002). Location, location! Sports history and academic real estate. Australian Society for Sports History Bulletin, 36: 11-14.

Adair, D. (1998). Conformity, diversity, and difference in antipodean physical culture: the indelible influence of immigration, ethnicity, and race during the formative years of organised sport in Australia, c. 1788-1918. In M. Cronin and D. Mayall (Eds). Sporting nationalisms: identity, ethnicity, immigration, and assimilation (pp. 14-48). London: Frank Cass.

Adair, D. (1994). Rowing and sculling. In W. Vamplew \& B. Stoddart (Eds). Sport in Australia: a social history (pp. 172-92). Melbourne: Cambridge University Press.

Adair, D. (1992). Two dots in the distance: professional sculling as a mass spectacle in New South Wales, 1876-1907. Sporting Traditions, 9(1): 52-83.

Adair, D., Phillips, M. \& Nauright, J. (1997). Sporting manhood in Australia: test cricket, rugby football, and the Imperial connection, 1878-1918. Sport History Review, 28: 46-60.

Adair, D. \& Vamplew, W. (1997). Sport in Australian history. Oxford: Oxford University Press.

Ahearne, K. (1987). The myth lives on: cultural significance of the Melbourne Cup. Australian Society, $6(12): 52,57-58$.

Atherley, K. (2006). Sport, localism and social capital in rural Western Australia. Geographical Research, 44(4): $348-60$.

Australian Sports Commission (2009). Yulunga: traditional Aboriginal games. [Online]. Available: www. ausport.gov.au/participating/indigenous/resources/games_and_activities/full_resource [accessed 21 February 2010].

Bairner, A. (2007). Wearing the baggie green: the Irish and Australian cricket. Sport in Society, 10(3): $457-75$. 
$14 \cdot$ Youth sport in Australia

Bale, J. (2003). Sports geography. London: Routledge.

Bale, J. (1994). Landscapes of modern sport. Leicester: Leicester University Press.

Bennett, S. (1998). Regional sentiment and Australian sport. Sporting Traditions, 5(1): 98-111.

Beresford, Q. (1982). The Melbourne Cup: Australia's first national day. Hemisphere, 27: 180-84.

Blades, G. C. (1985). Australian Aborigines, Cricket and Pedestrianism: Culture and Conflict, 18801910, Honours thesis, Bachelor of Human Movement Studies, University of Queensland.

Blainey, G. (1966). The tyranny of distance: how distance shaped Australia's history. Melbourne: Sun Books.

Blair, D. J. (1995). The greater game: Australian football and the army at home and on the front during World War I. Sporting Traditions, 11(2): 91-102.

Blashak, B. (2004). 'The ignorant labelled it a ladies' game': masculinity in Australian tennis in the late nineteenth and early twentieth centuries. In I. Warren (Ed.). Sport, gender and theory: the formative years of tennis and snowboarding (pp. 1-59). ASSH Studies 16, Melbourne: Australian Society for Sports History.

Bonnell, M. (2003). How many more are coming? The short life of Jack Marsh. Petersham, NSW: Walla Walla Press.

Booth, D. (2006). Sites of truth or metaphors of power? Refiguring the archive. Sport in History, 26(1): 91-109.

Booth, D. (2005a). The field: truth and fiction in sport history. London: Taylor \& Francis.

Booth, D. (2005b). Evidence revisited: interpreting historical materials in sport history. Rethinking History, 9(4): 459-83.

Booth, D. (2004). Escaping the past? The cultural turn and language in sport history. Rethinking History, $8(1): 103-25$.

Booth, D. (2002). A tragic plot? A reply to Jaggard and Phillips. Journal of Sport History, 29(1): 41-48.

Booth, D. (2001a). The dark side of surf lifesaving. Journal of Sport History, 29(1): 7-14.

Booth, D. (2001b). Australian beach cultures: the history of sun, sand, and surf. London: Frank Cass.

Booth, D. (2001c). From bikinis to boardshorts: wahines and the paradoxes of surfing culture. Journal of Sport History, 28(1): 3-22.

Booth, D. (2000). Surf lifesaving: the development of an Australasian sport. International Journal of the History of Sport, 17(2): 166-87.

Booth, D. (1997). Sports history: what can be done? Sport, Education and Society, 2(2): 191-204.

Booth, D. (1995). Ambiguities in pleasure and discipline: the development of competitive surfing. Journal of Sport History, 22: 189-206.

Booth, D. (1994a). Swimming, surfing and surf-lifesaving. In W. Vamplew \& B. Stoddart (Eds). Sport in Australia: a social history (pp. 231-54). Melbourne: Cambridge University Press.

Booth, D. (1994b). Surfing '60s: a case study in the history of pleasure and discipline. Australian Historical Studies, 26(103): 262-79.

Booth, D. (1991). War off the water: the Australian Surf Lifesaving Association and the beach. Sporting Traditions, $7(2): 134-62$. 
Bowden, B. (2003). Nationalism and cosmopolitanism: irreconcilable differences or possible bedfellows? National Identities, 5(3): 235-49.

Brabazon, T. (2000). Time for a change or more of the same? Les Mills and the masculinisation of aerobics. Sporting Traditions, 17(1): 97-112.

Brawley, S. (2009). 'They came, they saw, they conquered': the Takaishi/Saito tour of 1926-27 and Australian perceptions of Japan. Sporting Traditions, 26(2): 49-66.

Brawley, S. (1995). Vigilant and victorious: a community history of the Collaroy Surf Life Saving Club, 1911-1995. Collaroy, NSW: Collaroy Surf Life Saving Club.

Brice, I. D. (2001). Ethnic masculinities in Australian boys' schools: Scots and Irish secondary schools in late nineteenth-century Australia. Paedagogica Historica, 37(1): 139-52.

Broome, R. (1996). Theatres of power: tent boxing circa 1910-1970. Aboriginal History, 20:1-23.

Broome, R. (1980). Professional Aboriginal boxers in eastern Australia 1930-1979. Aboriginal History, 4(1-2): 49-71.

Broome, R. (1979). The Australian reaction to Jack Johnson, black pugilist, 1907-09. In R. Cashman \& M. McKernan (Eds). Sport in History (pp. 343-63). St Lucia: University of Queensland Press.

Brown, D. W. (1987). Muscular Christianity in the Antipodes: some observations on the diffusion and emergence of a Victorian ideal in Australian social theory. Sporting Traditions, 3(2): 173-87.

Brown, P. (1995). Gender, the press and history: coverage of women's sport in the Newcastle Herald, 1890-1990. Media Information Australia, 75: 24-34.

Bruce, T. \& Hallinan, C. (2001). Cathy Freeman: the quest for Australian identity. In D. Andrews and S. Jackson (Eds). Sports stars: the cultural politics of sporting celebrity (pp. 257-70). New York: Routledge.

Burroughs, A. (2001). Women, femininity and sport: the contribution of the 'new woman' to nationhood. In R. Cashman, J. O'Hara \& A. Honey (Eds). Sport, federation, nation (pp. 165-80). Sydney: Walla Walla Press.

Burroughs, A. \& Nauright, J. (2000). Women's sports and embodiment in Australia and New Zealand. In J.A. Mangan \& J. Nauright (Eds). Sport in Australasian society: past and present (pp. 188-205). London: Frank Cass.

Cashman, R. (1995). Paradise of sport: the rise of organised sport in Australia. Melbourne: Oxford University Press.

Cashman, R. (1992). Symbols of Imperial unity: Anglo-Australian cricketers, 1877-1900. In J. A. Mangan (Ed.). The cultural bond: sport, empire, society (pp. 129-41). Frank Cass: London.

Cashman, R. \& Hickie, T. (1987). The divergent sporting cultures of Sydney and Melbourne. Sporting Traditions, $7(1): 24-46$.

Cohen, P. (2006). Behind barbed wire: sport and Australian prisoners of war. Sporting Traditions, 23(1): 63-86.

Collins, T. (2005). Australian nationalism and working-class Britishness: the case of Rugby League football. History Compass, 3(1): 1-19.

Collins, T. (2000). From Bondi to Batley: Australian players in British rugby league, 1907-1995. Sporting Traditions, 16(2): 7I-86. 
Collins, B, Aitken, M. \& Cork, B. (1990). One hundred years of public school sport in New South Wales 1889-1989. Sydney: New South Wales Department of School Education.

Colman, M. \& Edwards, K. (2002). Eddie Gilbert: the true story of an Aboriginal cricketing legend. Sydney: ABC Books, Sydney.

Connellan, M. (1988). The ideology of athleticism, its Antipodean impact, and its manifestation in two elite Catholic schools. Bedford Park SA: ASSH Studies in Sports History, 5.

Crawford, R. (1986). Athleticism, gentlemen and Empire in Australian public schools: L. A. Adamson and Wesley College, Melbourne. In W. Vamplew (Ed.). Sport and colonialism in 19th century Australasia (pp. 42-64). Bedford Park SA: ASSH Studies in Sports History, 1.

Crawford, R. (1984). Sport for young ladies: the Victorian Independent Schools 1875-1925. Sporting Traditions, I(1): 61-82.

Cronin, M. (1996). Defenders of the nation? The Gaelic Athletic Association and Irish nationalist identity. Irish Political Studies, 11(1): 1-19.

Crotty, M. (2001). Making the Australian male: middle-class masculinity 1870-1920. Melbourne: Melbourne University Publishing.

Crotty, M. (2000). Manly and moral: the making of middle-class men in the Australian public school. International Journal of the History of Sport, 17(2): 10-30.

Crotty, M. (1998). Separate and distinct? The manual labour question in nineteenth-century Victorian rowing. International Journal of the History of Sport, 15(2): 152-63.

Cunneen, C. (1981). Elevating and recording the people's pastimes: Sydney sporting journalism 1886-1939. In R. Cashman \& M. McKernan (Eds). Sport: money, morality, and the media (pp. 162-76). Sydney: UNSW Press.

Cunneen, C. (1979). The rugby war: the early history of Rugby League in New South Wales. In R. Cashman \& M. McKernan (Eds). Sport in history: the making of modern sport history (pp. 293-306). St Lucia Qld: University of Queensland Press.

Dabscheck, B. (2007). Moving beyond ethnicity: soccer's evolutionary progress. In B. Stewart (Ed.). The games are not the same: the political economy of football in Australia (pp. 198-235). Carlton Victoria: Melbourne University Press.

Dabscheck, B. (1998). Australian baseball's second unsuccessful attempt to establish a players' association. Sporting Traditions, 14(2): 87-90.

Dabscheck, B. (1991). The Professional Cricketers Association of Australia. Sporting Traditions, 8(1): 2-27.

Daley, C. (2005). From bush to beach: nudism in Australasia. Journal of Historical Geography, 31(1): 149-67.

Daly, J. A. (1994). Track and field. In W. Vamplew and B. Stoddart (Eds). Sport in Australia: a social history (pp. 255-68). Melbourne: Cambridge University Press.

Daly, J. A. (1982). Elysian fields: sport, class and community in colonial South Australia, 1836-1890. Adelaide: J.A. Daly.

Danforth, L. M. (2001). Is the 'world game' an 'ethnic game' or an 'Aussie game'? Narrating the nation in Australian soccer. American Ethnologist, 28(2): 363-87. 
Drew, P. (1994). The coast dwellers: Australians living on the edge. Ringwood: Penguin.

Edwards, K. (2009). Traditional games of a timeless land: play cultures in Aboriginal and Torres Strait Islander communities. Australian Aboriginal Studies (2): 32-43.

Edwards, K. (1999). Choopadoo: games from a Dreamtime. Brisbane: Queensland University of Technology Press.

Fewster, K. (1985). Advantage Australia: Davis Cup tennis 1950-1959. Sporting Traditions, 2(1): 47-68.

Forster, C. (1986). Sport, society and space: the changing geography of country cricket in South Australia 1836-1914. Sporting Traditions, 2(2): 23-47.

Gardiner, G. (1997). Racial abuse and football: the Australian Football League's racial vilification rule in review. Sporting Traditions, 14(1): 3-26.

Georgakis, S. (2000). Sport and the Australian Greek. Sydney: Standard Publishing.

Goolagong Cawley, E. \& Jarratt, P. (1993). Home! The Evonne Goolagong story. East Roseville, NSW:

Simon \& Schuster.

Gorman, S. (2005). Brotherboys: the story of Jim and Phillip Krakouer. Crows Nest, NSW: Allen \& Unwin. Griffen-Foley, B. (2000). Playing with princes and presidents: Sir Frank Packer and the 1962 challenge for the America's Cup. Australian Journal of Politics \& History, 46(1): 51-66.

Grow, R. (1986). Nineteenth century football and the Melbourne press. Sporting Traditions, 3(1): 23-37.

Guoth, N. (2007). Kangaroos and dragons: the 1923 Chinese football tour of Australia, Paper Presented to Sporting Traditions XVI, the Biennial Conference of the Australian Society for Sports History, Canberra, 27-30 June 2007.

Guttmann, A. (2008). Review essay: the ludic and the ludicrous. International Journal of the History of Sport, 25(1): 100-12.

Haig-Muir, M. (2004). Handicapped from birth? Why women golfers are traditionally a fairway behind. Sport History Review, 35(1): 64-82.

Haig-Muir, M. (2000). Many a slip twixt cup and the lip: equal opportunity and Victorian golf clubs. Sporting Traditions, I7(1): 19-38.

Haigh, G. (2004). Pascoe was like a bull at a batsman. The Age, 21 February.

Haigh, G. \& Dundas, R. (2001). The cricket war: the inside story of Kerry Packer's World Series Cricket, Melbourne: Text Publishing Company.

Halladay, E. (1990). Rowing in England. A social history: the amateur debate, Manchester: Manchester University Press.

Harriss, I. (1990). Packer, cricket and postmodernism. In D. Rowe \& G. Lawrence (Eds). Sport and leisure: trends in Australian popular culture (pp. 109-21). Sydney: Harcourt Brace Jovanovich.

Hay, R. (2006a). 'Our wicked foreign game': why has association football (soccer) not become the main code of football in Australia? Soccer and Society, 7(2): 165-86.

Hay, R. (2006b). Approaches to sports history: theory and practice. Sporting Traditions, 22(2): 70-81. 


\section{$18 \cdot$ Youth sport in Australia}

Hay, R. (2001). 'Those bloody Croatians': Croatian soccer teams, ethnicity and violence in Australia, 1950-99. In G. Armstrong \& R. Giulianotti (Eds). Fear and loathing in world football (pp. 77-90). Oxford: Berg.

Hay, R. (1998). Croatia: community, conflict and culture: the role of soccer clubs in migrant identity. Immigrants And Minorities, 17: 49-66.

Headon, D. (2009). 'World's Fistanic History', Sydney 1908: 'Flash Jack Johnson' vs 'Sinking Tommy Burns'. Sporting Traditions, 26(2): 1-14.

Hess, R. (2005). 'For the love of sensation': case studies in the early development of wormen's football in Victoria, 1921-1981. Football Studies, 8(2): 20-30.

Hess, R. (2000). 'Ladies are specially invited': women in the culture of Australian Rules Football. International Journal of the History of Sport, 17(2): $111-41$.

Hess, R. (1998). A mania for bicycles: the impact of cycling on Australian Rules Football. Sporting Traditions, I4(2): 3-24.

Hess, R. (1996). Women and Australian Rules Football in colonial Melbourne. International Journal of the History of Sport, 13(3): 356-72.

Hickey, C. (2008). Physical education, sport and hyper-masculinity in schools. Sport, Education and Society, 13(2): 147-61.

Hirst, J. B. (2006). Sense and nonsense in Australian history. Melbourne: Black Inc.

Hirst, J. B. (1983). Convict society and its enemies: a history of early New South Wales. Sydney: Allen \& Unwin. Hogan, M. C. (1987). The sectarian strand: religion in Australian history. Ringwood, Vic.: Penguin Books. Holt, R. (1989). Sport and the British: a modern history. Oxford: Oxford University Press.

Honey, A. (2001). Sport, immigration restriction and race: the operation of the White Australia Policy. In R. Cashman, J. O'Hara \& A. Honey (Eds). Sport, federation, nation (pp. 26-46). Sydney: Walla Walla Press.

Horton, P. A. (2006). Football, identity, place: the emergence of rugby football in Brisbane. International Journal of the History of Sport, 23(8): 1341-68.

Horton, P. A. (1994). Dominant ideologies and their role in the establishment of rugby union football in Victorian Queensland. International Journal of the History of Sport, 11(1): 115-28.

Howell, R. A. \& Howell, M. L. (1992). The genesis of sport in Queensland. St Lucia: University of Queensland Press, 1992.

Hughes, A. (1999). Sport in the Australian Jewish community. Journal of Sport History, 26(2): 376-91.

Hughes, A. (1996). Muscular Judaism and the Jewish rugby league competition in Sydney, 1924 to 1927. Sporting Traditions, 13(1): 61-80.

Hughes, R. (1987). The fatal shore: a history of the transportation of convicts to Australia, 1787-1868. New York: Random House.

Hughson, J. (2001). 'The wogs are at it again': the media reportage of Australian soccer 'riots'. Football Studies, (1): 40-55.

Hughson, J. (2000). The boys are back in town: soccer support and the social reproduction of masculinity. Journal of Sport and Social Lssues, 24(1): 8-23. 
Hughson, J. (1997). Football, folk dancing and fascism: diversity and difference in multicultural Australia. Journal of Sociology, 33(2): 167-86.

Hughson, J. (1992). Australian soccer: 'ethnic' or 'Aussie'. The search for an image. Current Affairs Bulletin, 68(10): 12-16.

Hutchins, B. \& Phillips, M.G. (1997). Selling permissible violence: the commodification of Australian Rugby League 1970-1995. International Review for the Sociology of Sport, 32(2): 161-76.

Jaggard, E. (Ed.) (2006). Between the flags: one hundred summers of Australian surf lifesaving, Kensington: UNSW Press.

Jaggard, E. (2002). Writing Australian surf lifesaving's history. Journal of Sport History, 29(1): 15-24.

Jaggard, E. (2001). Tempering the testosterone: masculinity, women and Australian surf lifesaving. The International Journal of the History of Sport, 18(4): 16-36.

Jaggard, E. (1996). Forgotten heroes: the 1945 Australian Services cricket team. Sporting Traditions, 12(2): $61-79$.

Jobling, I. (1988). The making of a nation through sport: Australia and the Olympic Games from Athens to Berlin, 1898-1916. Australian Journal of Politics \& History, 34(2): 160-72.

Johnes, M. (2007). Archives, truths and the historian at work: a reply to Douglas Booth's 'refiguring the archive. Sport in History, 27(1): 127-35.

Jupp, J. (1991). One among many: the relative success of Australian multiculturalism. In D. Goodman, C. Wallace-Crabbe \& D. O'Hearn (Eds). Multicultural Australia (pp. 119-33). Newham, Vic.: Scribe.

Kildea, J. (2002). Tearing the fabric: sectarianism in Australia 1910 to 1925. Sydney: Citadel Books.

Kinross-Smith, G. (1997). Privilege in tennis and lawn tennis: the Geelong and Royal South Yarra examples: but not forgetting the story of the farmer's wrist. Sporting Traditions, 3(2): 189-216.

Kinross-Smith, G. (1994). Lawn tennis. In W. Vamplew \& B. Stoddart (Eds). Sport in Australia: a social history (pp. 133-52). Melbourne: Cambridge University Press.

Kirk, D. (2000). Gender associations: sport, state schools and Australian culture. International Journal of the History of Sport, 17(2): 49-64.

Kirk, D. (1996). Foucault and the limits of corporeal regulation: the emergence, consolidation and decline of school medical inspection and physical training in Australia, 1909-30. International Journal of the History of Sport, 13(2): 114-31.

Kirk, D. \& Twigg, K. (1995). Civilising Australian bodies: the games ethic and sport in Victorian government schools, 1904-1945. Sporting Traditions, 11(2): 3-34.

Kirk, D. \& Twigg, K. (1993). The militarization of school physical training in Australia: the rise and demise of the junior cadet training scheme, 1911-31. History of Education, 22(4): 391-414.

Korff, J-U. (2009). Aboriginal Indigenous Sport. [Online]. Available: www.creativespirits.info/ aboriginalculture /sport/ [accessed 7 January 2009].

Lawrence, G. A. \& Rowe, D. (Eds) (1986). Power play: essays in the sociology of Australian sport, Sydney: Hale \& Iremonger. 
Lawson, G. (1993). Henry: the Geoff Lawson story. Randwick, NSW: Ironbark Press.

Light, R. \& Kirk, D. (2001). Australian cultural capital - rugby's social meaning: physical assets, social advantage and Independent schools. Culture, Sport, Society, 4(3): 81-98.

Light, R. \& Kirk, D. (2000). High school rugby, the body and the reproduction of hegemonic masculinity. Sport, Education and Society, 5(2): 163-76.

Little, C. (2007). The 'hidden' history of the birth of Rugby League in Australia: the significance of local factors in Sydney's rugby split. Sport in History, 27(3): 364-79.

Little, C. (2001). 'What a freak-show they made!' Women's rugby league in 1920s Sydney. Football Studies, 4(2): 25-40.

Lock, D. (2009). Fan perspectives of change in the A-League. Soccer and Society, 10(1): 109-23.

Lock, D., Taylor, T. \& Darcy, S. (2008). Soccer and social capital in Australia: social networks in transition. In M. Nicholson and R. Hoye (Eds). Sport and social capital (pp. 317-38). Oxford:

Butterworth-Heinemann.

Lothian, K. (2007). Moving blackwards: black power and the Aboriginal embassy. In I. MacFarlane and M. Hannah (Eds). Transgressions: critical Australian Indigenous histories (pp. 19-34). Aboriginal History Monograph 16, Canberra: ANU e-Press.

Magdalinksi, T. (2002). Cricket and regional development on the sunshine coast. Sporting Traditions, 18(2): 15-29.

Mandle, W. F. (1973). Cricket and Australian nationalism in the nineteenth century. Journal of the Royal Australian Historical Society, 59(4): 225-46.

Mason, P. (1985). Professional athletics in Australia. Adelaide: Rigby.

McGregor, R. (2006). The necessity of Britishness: ethno-cultural roots of Australian nationalism. Nations and Nationalism, 12 (3): 493-511.

McKay, J. (1991). No pain, no gain? Sport and Australian culture. Sydney: Prentice Hall.

McDermott, M-L. (2005). Changing visions of baths and bathers: desegregating ocean baths in Wollongong, Kiama and Gerringong. Sporting Traditions, 22(1): 1-19.

McDevitt, P. F. (1997). Muscular Catholicism: nationalism, masculinity and Gaelic team sports, 18841916. Gender and History, 9(2): 262-84.

McKernan, M. (1979). Sport, war and society: Australia, 1914-1918. In R. Cashman \& M. McKernan (Eds). Sport in history: the making of modern sporting history (pp. 1-20). St Lucia: University of Queensland Press.

McNamara, L. (2000). Tackling racial hatred: conciliation, reconciliation and football. Australian Journal of Human Rights, 6(2): 5-31.

Meaney, N. (2001). Britishness and Australian identity: the problem of nationalism in Australian history and historiography. Australian Historical Studies, 32(116): 76-90.

Mooney, C. \& Ramsland, J. (2008). Dave Sands as local hero and international champion: race, family and identity in an industrial working-class suburb. Sport in History, 28(2): 299-312. 
Moore, A. (1996). The mighty Bears!: a social history of North Sydney Rugby League. Sydney: Macmillan. Moore. K. \& Phillips, M. G. (1990). The sporting career of Harold Hardwick: one example of the irony of the amateur-professional dichotomy. Sporting Traditions, 7(1): 61-76.

Mosely, P. (1997). Sporting immigrants: sport and ethnicity in Australia. Sydney: Walla Walla Press. Mosely, P. (1995). Ethnic involvement in Australian soccer: a history 1950-1990. Canberra: National Sports Research Centre.

Mulvaney, J \& Harcourt, R. (1988). Cricket walkabout: the Australian Aborigines in England. South Melbourne: Macmillan.

Nauright, J. \& Chandler, T. J. L. (Eds) (1996). Making men: rugby and masculine identity. London: Frank Cass Publishers.

Nauright, J. \&. Phillips, M. (1997). Us and them: Australian professional sport and resistance to North American ownership and marketing models. Sport Marketing Quarterly, 6(1): 33-39.

Nauright, J. \& Phillips, M. (1996). A fair go for the fans?: super leagues, sports ownership and fans in Australia. Social Alternatives, 15(4): 43-45.

Newlin, N. \& Moran, C. (1999). Living cultures. In R. Craven, Teaching Aboriginal studies (p. 35). Sydney: Allen \& Unwin.

Norris, R. (1975). The emergent Commonwealth: Australian federation, expectations and fulfilment 1889-1910. Melbourne: Melbourne University Press.

O'Hara, J. (2007). Globalisation, historical consciousness and the Melbourne Cup. Sporting Traditions, 23(2): $33-46$.

O'Hara, J. (2002). Big river racing: a history of the Clarence River Jockey Club 1861-2001. Kensington: UNSW Press.

O'Hara, J. (1994). Horse racing and trotting. In W. Vamplew \& B. Stoddart (Eds). Sport in Australia: a social history (pp. 93-111). Melbourne: Cambridge University Press.

O'Hara, J. (1991). The Jockey Club and the town in colonial Australia. Journal of Gambling Studies, 7(3): 207-15.

Osmond, G. \& McDermott, M-L. (2008). Mixing race: the Kong Sing brothers and Australian sport. Australian Historical Studies, 39(3): 338-55.

Osmond, G. \& Phillips, M. G. (2006). 'Look at that kid crawling': race, myth and the 'crawl' stroke. Australian Historical Studies, 37(127): 43-62.

Osmond, G. \& Phillips, M. G. (2004). The bloke with a stroke. Journal of Pacific History, 39(3): 309-24.

Payne, R. (2004). Rethinking the status of female Olympians in the Australian press. Media International Australia incorporating Culture and Policy, 110: 120-31.

Phillips. M. G. (Ed.) (2006). Deconstructing sport history: a postmodern analysis. New York: State University of New York Press.

Phillips, M. G. (2002). A critical appraisal of narrative in sport history: reading the surf lifesaving debate. Journal of Sport History, 29(1): 25-40. 
Phillips, M. G. (2001a). Diminishing contrasts and increasing varieties: globalisation theory and 'reading' amateurism in Australian sport. Sporting Traditions, 18(1): 19-32.

Phillips, M. G. (1998). Public sports history, history and social memory: (re)presenting swimming in Australia. Sporting Traditions, 15(1): 93-102.

Phillips, M. G. (1997). Sport, war and gender images: the Australian sportsmen's battalions and the First World War. International Journal of the History of Sport, 14(1): 78-96.

Phillips, M. G. (1996). Football, class and war: the rugby codes in New South Wales, 1907-15. In J. Nauright \& T. J. L. Chandler (Eds). Making men: rugby and masculine identity (pp. 158-80). London: Frank Cass.

Phillips, M. G. (1990). Golf and Victorian sporting values.Sporting Traditions, 6(2): 120-34.

Phillips, M. G. (1988). Ethnicity and class at the Brisbane Golf Club. Sporting Traditions, 4(2): 201-13.

Phillips, M. G. \& Hutchins, B. (2003). Losing control of the ball: the political economy of football and the media in Australia. Journal of Sport and Social Issues, 27(3): 215-32.

Phillips, M. G. \& Nauright, J. (1999). Sports fan movements to save suburban-based football teams threatened with amalgamation in different football codes in Australia. International Sports Studies, 21(1): 16-38.

Ramsland, J. (2004). A remarkable life: Roden Cutler as sporting, military and local hero. Sporting Traditions, 20(2): 39-54.

Randall, L. M. (1988). A fair go?: women in sport in South Australia, 1945-1965, ASSH Studies 6, Bedford Park SA: Australian Society for Sports History.

Reynolds, H. (2006). The other side of the frontier: Aboriginal resistance to the European invasion of Australia. Kensington: UNSW Press.

Reynolds, H. (1996). Dispossession: black Australians and white invaders. Sydney: Allen \& Unwin.

Ripley, S. (2005). The golden age of Australian professional sculling or skullduggery? International Journal of the History of Sport, 22(5): 867-82.

Ripley, S. (2003). A social history of New South Wales professional sculling, 1876-1927, unpublished $\mathrm{PhD}$ thesis, School of Arts and Humanities, University of Western Sydney.

Ritchie, A. (2011). Major Taylor: understanding the complex story of a champion African-American cyclist in white Australia, 1903-04. In D. Adair (Ed.). Sport, race and ethnicity: narratives of difference and diversity. Morgantown WV: FIT Publishing, (in press).

Ritchie, A. (1996). Major Taylor: the extraordinary career of a champion bicycle racer. Baltimore MA: Johns Hopkins University Press.

Rodwell, G. \& Ramsland, J. (2000). Cecil Healy: a soldier of the surf. Sporting Traditions, 16(2): 3-16.

Rose, L \& Humphries, R. (1969). Lionel Rose Australian: the life story of a champion [As told to Humphries by Rose]. Sydney: Angus and Robertson.

Ross, J. (1984). Pedestrianism and athletics in England and Australia in the nineteenth century: a case study in the development of sport, Bachelor of Human Movement Studies (Hons) thesis, University of Queensland, St Lucia. 
Rowe, D. (1999). Sport, culture and the media. Buckingham: Open University Press.

Rowe, D. \& Lawrence, G. (Eds) (1990). Sport and leisure: trends in Australian popular culture. Sydney: Harcourt Brace Jovanovich.

Sampson, D. (2009). Culture, 'race' and discrimination in the 1868 Aboriginal cricket tour of England. Australian Aboriginal Studies, (2): 44-60.

Sampson, D. (2000). Strangers in a strange land: the 1868 Aborigines and other Indigenous performers in mid-Victorian Britain, PhD thesis, Faculty of Humanities and Social Sciences, University of Technology Sydney, Australian Digital Thesis Repository, hdl.handle.net/2100/314.

Saunders, K. (1998). Specimens of superb manhood: the lifesaver as national icon. Journal of Australian Studies, 56: 96-105.

Seal, G. (2004). Inventing ANZAC: the digger and national mythology. St Lucia: University of Queensland Press.

Senyard, J. (2002). From gentleman to the manly: a large step for the amateur. Sporting Traditions, 18(2): $1-14$.

Shannon, N. (2004). The friendly games? Politics, protest and Aboriginal rights at the XII Commonwealth Games, Brisbane 1982. In I. Warren (Ed.). Buoyant nationalism: Australian identity, sport and the world stage, 1982-1983 (pp. 1-59). ASSH Studies, 14. Melbourne: Australian Society for Sports History.

Sherington, G. (1983). Athleticism in the Antipodes: the Athletic Association of the Great Public Schools of New South Wales. History of Education Review, 12(2): 16-28.

Simpson, C. S. (Ed.) (2006). Scorchers, ramblers and rovers: Australasian cycling histories, ASSH Studies 21, Melbourne: Australian Society for Sports History.

Skinner, J. (2008). Coming in from the margins: ethnicity, community support and the rebranding of Australian soccer. Soccer and Society, 9(3): 394-404.

Smith, L., McCalman, J., Anderson, I., Smith, S., Evans, J., McCarthy, G. \& Beer, J. (2008). Fractional identities: the political arithmetic of Aboriginal Victorians. Journal of Interdisciplinary History, 38(4): $533-51$.

Stell, M. K. (1991). Half the race: a history of Australian women in sport. North Ryde, NSW: Angus \& Robertson.

Stremski, R. (1986). Kill for Collingwood. Sydney: Allen \& Unwin.

Stewart, B. (Ed.) (2007). The games are not the same: the political economy of football in Australia. Carlton, Vic.: Melbourne University Press.

Stewart, B. (2003). The crisis of confidence in Australian first-class cricket in the 1950s. Sporting Traditions, 20(1): 43-62.

Stewart, B. (2002). Radio's changing relationship with Australian cricket: 1932-1950. Sporting Traditions, 19(1): 49-64.

Stewart, B. (1995). 'I heard it on the radio, I saw it on the television': the commercial and cultural development of Australian first class cricket: 1946-1985, Unpublished PhD thesis, School of History, La Trobe University, Melbourne. 


\section{$24 \cdot$ Youth sport in Australia}

Stewart, B. (1992). Athleticism revisited: sport, character building and Protestant school education in nineteenth century Melbourne. Sporting Traditions, 9(1): 35-50.

Stewart, B. (1985). The Economic Development of the Victorian Football League 1960-1984. Sporting Traditions, 1(2): 2-26.

Stocks, G. \& East, A. (2000). Lewie, Lewie. Chris Lewis: an Aboriginal champion. Perth: Specialist Sports Management.

Stoddart, B. (2006). In search of meaning: historians and their work. Sporting Traditions, 22(2): 82-87.

Stoddart, B. (1994). Golf. In W. Vamplew \& B. Stoddart (Eds). Sport in Australia: a social history (pp. 77-92). Melbourne: Cambridge University Press.

Stoddart, B. (1986). Saturday afternoon fever: sport in the Australian culture. Sydney: Angus and Robertson.

Stronach, M. M. \& Adair, D. (2010). Lords of the square ring: future capital and career transition issues for elite Indigenous Australian boxers. Cosmopolitan Civil Societies: An Interdisciplinary Journal, 2(2): 46-70.

Tatz, C. (2002). A course of history: Monash Country Club 1931-2001. Sydney: Allen \& Unwin.

Tatz, C. (1995). Obstacle race: Aborigines in sport. Kensington: UNSW Press.

Tatz, C. (1987). Aborigines in Sport. ASSH Studies 3: Bedford Park SA.

Tatz, C. (1984). Race, politics and sport. Sporting Traditions, 1(I): 2-36.

Tatz, C. (1981). Aborigines and the Commonwealth Games. Social Alternatives, 3(1): 48-51.

Tatz, C. \& Stoddart, B. (1993). The Royal Sydney Golf Club: the first hundred years. Sydney: Allen \& Unwin.

Tatz, C. \& Tatz, P. (2000). Black gold: the Aboriginal and Islander sports hall of fame. Canberra: Aboriginal Studies Press.

Tatz, C. \& Tatz, P. (1996). Black diamonds: the Aboriginal and Islander sports hall of fame. St. Leonards, NSW: Allen \& Unwin.

Taylor, T. (2005). Gendering sport: the development of netball in Australia. Sporting Traditions, 22(1): $57-74$.

Taylor, T. \& Toohey, K. (1998). Negotiating cultural diversity for women in sport: from assimilation to multiculturalism. Race, Ethnicity and Education, 1(1): 75-90.

Thompson, C. (2004). Boats, Bondy and the boxing kangaroo: the 1983 America's Cup. In I. Warren (Ed.). Buoyant nationalism: Australian identity, sport, and the world stage 1982-1983 (pp. 60-117). ASSH Studies 14, Balaclava, Vic.: Australian Society for Sports History.

Topp, D. \& Nauright, J. (2004). Rugby league, community and identity in the Lockyer Valley, Queensland. Sporting Traditions, 21(1): 53-65.

Tranter, N. (1998). Sport, economy, and society in Britain, 1750-1914. Cambridge: Cambridge University Press.

Treagus, M. (2005). Playing like ladies: basketball, netball and feminine restraint. International Journal of the History of Sport, 22(1): 88-105. 
Vamplew, W. (1988). Pay up and play the game: professional sport in Britain, 1875-1914. Cambridge: Cambridge University Press.

Vamplew, W. (1976). The turf: a social and economic history of horseracing. London: Allen Lane.

Warren, I. (2003). Football, crowds and cultures. Comparing English and Australian law and enforcement trends, ASSH Studies in Sport History, 13, Canberra: Australian Society for Sports History.

Warren, I. (2000). Combating vilification: the AFL and NRL anti-vilification rules. ANZSLA Commentator, 9(4): 13-15.

Warren, I. (1997). Racism and the law in Australian Rules Football: a critical analysis. Sporting Traditions, 14(1): 27-53.

Warren, J., Harper, A. \& Whittington, J. (2002). Sheilas, wogs and poofters: an incomplete biography of Johnny Warren and soccer in Australia. Sydney: Random House Australia.

Watson N. J., Weir, S. \& Friend, S. (2005). The development of muscular Christianity in Victorian Britain and beyond. Journal of Religion and Society, 7: 1-21.

Weaver, J. \& Weaver, J. T. (1999). We've had no punctures whatsoever: Dunlop, commerce and cycling in fin de siècle Australia. International Journal of the History of Sport, 16(3): 94-112.

Wells, J. (1998). Boxing Day: the fight that changed the world. Sydney: Harper.

Wenn, S. R. (1993). Lights, camera, little action: television, Avery Brundage and the 1956 Melbourne Olympics. Sporting Traditions, 10(1): 38-53.

Westerbeek, H., Deane, J. \& Smith, A. (2005). De-ethnicization and Australian soccer: the strategic management dilemma. International Journal of Sport Management, 6(3): pp. 270-88.

Whimpress, B. (2001). Absent Aborigines: the impact of Federation on Indigenous sport'. In R.

Cashman, J. O'Hara \& A. Honey (Eds). Sport, federation, nation (pp. 47-54). Sydney: Walla Walla Press.

Whimpress, B. (1999). Passport to nowhere: Aborigines in Australian Cricket, 1850-1939. Sydney: Walla Walla Press.

Whimpress, B. (1994). The Marsh-Maclaren dispute at Bathurst, 1902, and the politics of selection. Sporting Traditions, 10(2): 45-58.

Whimpress, B. (1992). Few and far between: prejudice and discrimination among Aborigines in Australian first class cricket 1869-1988. Journal of the Anthropological Society of South Australia, 30(1-2): $57-70$.

White, C. (2004). Picnicking, surf-bathing and middle-class morality on the beach in the eastern suburbs of Sydney, 1811-1912. Journal of Australian Studies, 80: 101-10.

White, R. (2003). National days and the national past in Australia. Australian Cultural History, 22: 55-72. Wilkinson, I. R. (1998). School sport and the amateur ideal: the formation of the Schools' Amateur Athletic Association of Victoria. Sporting Traditions, 15(1): 51-70. 